\title{
Fatty acid profile in edible eggs of snails from the Cornu genus
}

\author{
Monika Maćkowiak-Dryka ${ }^{1}$, Krzysztof Szkucik $^{1}$, \\ Monika Ziomek $^{1}$, Kamila Klimek ${ }^{2}$ \\ ${ }^{1}$ Department of Food Hygiene of Animal Origin, Faculty of Veterinary Medicine, \\ ${ }^{2}$ Department of Mathematical Statistics, Faculty of Production Engineering \\ University of Life Sciences in Lublin, 20-950 Lublin, Poland \\ monika.mackowiak@up.lublin.pl
}

Received: July 18, 2019 Accepted: March 5, 2020

\begin{abstract}
Introduction: The aim of this study was to determine the content of fatty acids in eggs harvested from two edible subspecies of Polish-bred common garden snail from the Cornu genus, as well as this content in the retail-ready product obtained from these eggs. Material and Methods: Material for the study consisted of eggs from two subspecies of edible snails: the small (Cornu aspersum aspersum), and large (Cornu aspersum maxima) common garden snails. The eggs studied were in two forms, the first of which had undergone initial processing to the half-product stage and the second of which was the final product available on the Polish market under the name "Snail Eggs". The gas chromatography method was used to determine the content of fatty acids. Results: More than $75 \%$ of the studied fats were saturated fatty acids, dominated by palmitic and stearic acids. The average content of polyunsaturated fatty acids was $0.37 \%$, and it was a combination of two acids: linoleic (C18:2n6c), and its trans isomer (C18:2n6t). No significant differences were found comparing individual fatty acids content between the two species' eggs as halfproducts, or between the half-products and the final product. Conclusion: The fat in raw and processed eggs of common garden snails holds low nutritional value, and the processing did not affect the content of fatty acids.
\end{abstract}

Keywords: Cornu aspersum, snail eggs, fatty acids.

\section{Introduction}

The most commonly consumed species of snail from the Helicidae family are the Roman snail (Helix pomatia), and common garden snails from the Cornu genus. Natural sources of common garden snails are nearly exhausted, and breeding farms, the number of which in Poland is increasing, are their source for the food industry. In 2017 the total number of breeding farms classified as companies from the aquaculture sector (under which legislation the whole mollusca phylum comes) in Poland was 556, and in 2019 was 826 $(11,18)$. Two naturalised subspecies of common garden snail are well adapted to conditions on farms, namely the small (Cornu aspersum aspersum) and large (Cornu aspersum maxima) common garden snails. Edible materials that include meat and eggs are obtained from these molluscs (10). Eggs laid by both subspecies of common garden snail constitute the raw material for the production of a delicacy called "white caviar", which in
Poland is marketed under the name "Snail Eggs". As real caviar supply falls due to a declining sturgeon population, alternatives are sought and this product has been classified as a caviar substitute (1). As a substitute, the snail egg product differs from traditional caviar in many ways, the principal aspects distinguishing it being colour, egg size, and taste (5).

Under farm conditions, snails lay eggs into incubation containers filled with soil. The number of eggs in a clutch, its mass, and the diameter of a single egg depend on the snail subspecies (5). The average mass of a single clutch of common garden snail eggs varies between 3 and $6 \mathrm{~g}$, and the diameter of a single egg is between 3 and $6 \mathrm{~mm}$ (15). The number of eggs laid simultaneously in a clutch from Cornu aspersum maxima falls between 120 and 250, and a clutch from Cornu aspersum aspersum consists of 80 to $150(13,15)$. Properly formed, healthy, fertilised eggs are spherical in shape, their colour is milky-white and pearlescent, and they are opaque rather than translucent (15). Collected 
eggs are transferred into sieves, and then rinsed with water and selected by hand. The processing of the final product takes place at $4^{\circ} \mathrm{C}$ in relative humidity of approximately $70 \%$ and includes weighing eggs into individual $50 \mathrm{~g}$ portions for retail in glass jars. Afterwards, brine based on sea salt and the water used in processing is poured over the eggs (5).

The available literature lacks data regarding the profile of fatty acids and their percentage in the fat of eggs from the common garden snail. It is only known that the fat in snail eggs occurs in trace amounts (3). According to Nunes Almeida (9), its content in raw large common garden snail eggs is $0.1 \%$. The level of fat in the caviar substitute discussed by Massari and Pastore (6) produced from small common garden snail eggs equalled $0.3 \%$. The goal of this study was to determine the content of fatty acids in eggs harvested from two edible subspecies of common garden snail from the Cornu genus, bred in Poland, as well as in the final product obtained from these eggs.

\section{Material and Methods}

The material was harvested during the production cycle; it consisted of the half-product and the final product. The half-product was eggs from two subspecies of edible snails, the small (Cornu aspersum aspersum) and large (Cornu aspersum maxima) common garden snails, which underwent initial processing, i.e. segregation, washing, and cold storage at $5^{\circ} \mathrm{C}$ for $24 \mathrm{~h}$. The final product is available on the Polish market under the name "Snail Eggs" in small glass jars containing eggs of both subspecies of common garden snail from the Cornu genus. Study samples each weighing $100 \mathrm{~g}$ and comprising the final product contents of two retail packages were transported at $4^{\circ} \mathrm{C}$ to the laboratory within $24 \mathrm{~h}$ of their harvesting.

Chemical analysis. The fatty acid profile was determined using the gas chromatography method. Fat extracted from the snails' eggs was weighed and added to glass ampoules at $100 \mathrm{mg}$ each, then saponified in $0.5 \mathrm{~N}$ methanolic $\mathrm{KOH}$ solution, evaporated at $86^{\circ} \mathrm{C}$, and finally esterified in $4 \mathrm{~mL}$ of $14 \%$ boron trifluoride. The obtained esters were salted out with $2 \mathrm{~mL}$ of saturated $\mathrm{NaCl}$ solution. Chromatographic separation was performed in a Varian 450 gas chromatograph (Agilent Technologies, Santa Clara, CA, USA) equipped with a split/splitless injector $\left(250^{\circ} \mathrm{C}\right)$ and flame ionisation detector $\left(300^{\circ} \mathrm{C}\right)$. The chromatograph was fitted with a Select TM Biodiesel for fatty acid methyl ester column (Agilent Technologies) of $30 \mathrm{~m}$ length and $0.32 \mathrm{~mm}$ of inner diameter. The initial column temperature was $200^{\circ} \mathrm{C}$ and a $3^{\circ} \mathrm{C} / \mathrm{min}$ increase up to $240^{\circ} \mathrm{C}$ was programmed. Helium was used as the carrier gas. The retention time readouts from the chromatograph served to identify particular fatty acids, while the relative percentage of fatty acids was calculated using the
GalaxieTM Chromatography Data System software package (Agilent Technologies).

Statistical analysis. The obtained results were analysed statistically with SAS Enterprise Guide 5.1 (SAS Institute, Cary, NC, USA) and expressed as the arithmetic means and standard deviation. The normal distribution in each group was checked with the Shapiro-Wilk test. Levene's test determined the homogeneity of their variance. The influence of each variability factor on the determined parameters was established using the one-way analysis of variance (ANOVA) for groups for which the assumption of homogeneous variances was fulfilled. Tukey's test was used as post-hoc analysis. The level of statistical significance was assumed at $\mathrm{P} \leq 0.05$.

\section{Results}

The percentage of fatty acids in the fat of both studied half-products and the final product is presented in Table 1. The analysis of results indicates that over $75 \%$ of the fat in both types of half-product and the final product consisted of saturated fatty acids (SFAs). In the fat from products at both stages eight acids were identified, in which the main components were palmitic (C16:0 - hexadecanoic) acid and stearic (C18:0 octadecanoic) acid. These two acids constituted approximately $81 \%$ of all fatty acids. The remaining acids included: capric (C10:0 - decanoic), lauric (C12:0 - dodecanoic), myristic (C14:0 - tetradecanoic), C15:0 (pentadecanoic), and margaric (C17:0 - heptadecanoic), and were present in markedly smaller amounts. The smallest constituent in this group of acids was C11:0 (undecanoic) acid. Comparing the content of individual SFAs - both between the half-products and between the half-products and the final product - no significant differences in their levels were found.

Monounsaturated fatty acids (MUFAs) constituted more than $23 \%$ of all identified fatty acids. The fat from the studied material contained three monoenoic acids, of which oleic (C18:1n9c-octadecanoic) acid and its trans isomer elaidic acid $(\mathrm{C} 18: \ln 9 \mathrm{t})$ together formed the highest content by a large margin. The lowest content was myristoleic acid (C14:1). No significant differences in the levels of respective acids between the two types of eggs when unprocessed or processed were found.

Polyunsaturated acids (PUFAs) comprised a small percentage in the fat of the studied half-products and final product. Only the combined content of two acids was determined: linoleic (C18:2n6c) acid and its trans isomer and linolelaidic acid (C18:2n6t), which in the cases of as-harvested eggs from the small common garden snail, large common garden snail, and as-sold "caviar" equalled $0.32 \%, 0.38 \%$, and $0.41 \%$, respectively. In the case of polyenoic acids there were also no differences between the two studied groups of half-products and the final product. 
Table 1. Fatty acid profile for the half-products and the final product (\%)

\begin{tabular}{|c|c|c|c|c|}
\hline & Acid & $\begin{array}{l}\text { Half-product CAA } \\
(\mathrm{n}=10)\end{array}$ & $\begin{array}{l}\text { Half-product CAM } \\
(\mathrm{n}=10)\end{array}$ & $\begin{array}{l}\text { Final product } \\
(\mathrm{n}=10)\end{array}$ \\
\hline \multirow{9}{*}{ Saturated acids } & C10:0 & $1.84 \pm 0.34$ & $1.31 \pm 0.29$ & $1.56 \pm 0.41$ \\
\hline & C11:0 & $0.63 \pm 0.21$ & $0.59 \pm 0.18$ & $0.53 \pm 0.16$ \\
\hline & $\mathrm{C} 12: 0$ & $3.82 \pm 0.93$ & $3.02 \pm 0.76$ & $3.21 \pm 0.79$ \\
\hline & $\mathrm{C} 14: 0$ & $6.68 \pm 0.98$ & $6.65 \pm 0.89$ & $6.3 \pm 0.73$ \\
\hline & $\mathrm{C} 15: 0$ & $1.45 \pm 0.24$ & $1.27 \pm 0.18$ & $1.32 \pm 0.21$ \\
\hline & $\mathrm{C} 16: 0$ & $39.35 \pm 3.42$ & $38.67 \pm 4.02$ & $39.24 \pm 4.33$ \\
\hline & $\mathrm{C} 17: 0$ & $1.14 \pm 0.18$ & $1.49 \pm 0.23$ & $1.26 \pm 0.2$ \\
\hline & C18:0 & $21.56 \pm 2.78$ & $22.27 \pm 3.01$ & $22.09 \pm 2.99$ \\
\hline & $\Sigma$ & $76.47 \pm 1.71$ & $75.27 \pm 1.94$ & $75.51 \pm 1.89$ \\
\hline \multirow{4}{*}{ Monounsaturated acids } & C14:1 & $0.39 \pm 0.12$ & $0.42 \pm 0.15$ & $0.41 \pm 0.13$ \\
\hline & C16:1 & $2.24 \pm 0.31$ & $3.26 \pm 0.42$ & $2.43 \pm 0.29$ \\
\hline & $\mathrm{C} 18: \ln 9 \mathrm{c}+\mathrm{C} 18: \ln 9 \mathrm{t}$ & $21.17 \pm 1.83$ & $19.84 \pm 1.79$ & $20.27 \pm 1.62$ \\
\hline & $\Sigma$ & $23.8 \pm 0.93$ & $23.52 \pm 0.89$ & $23.11 \pm 1.03$ \\
\hline Polyunsaturated acids & $\mathrm{C} 18: 2 \mathrm{n} 6 \mathrm{c}+\mathrm{C} 18: 2 \mathrm{n} 6 \mathrm{t}$ & $0.32 \pm 0.09$ & $0.38 \pm 0.07$ & $0.41 \pm 0.11$ \\
\hline
\end{tabular}

CAA - Cornu aspersum aspersum (small common garden snail); CAM - Cornu aspersum maxima (large common garden snail) No levels for the same fatty acid differed significantly within species or product stage

\section{Discussion}

The level of fat in raw and processed eggs of snails from the Cornu genus is low. The authors' own research showed that the fat content amounted to $0.09 \%$ in the final product, while in the eggs of the large and small common garden snails it reached $0.04 \%$ and $0.03 \%$, respectively (5). It contained saturated, monounsaturated, and polyunsaturated fatty acids. The ratio between the three groups of fatty acids in the eggs of common garden snails is unfavourable, due to the high level of SFAs (Fig. 1).

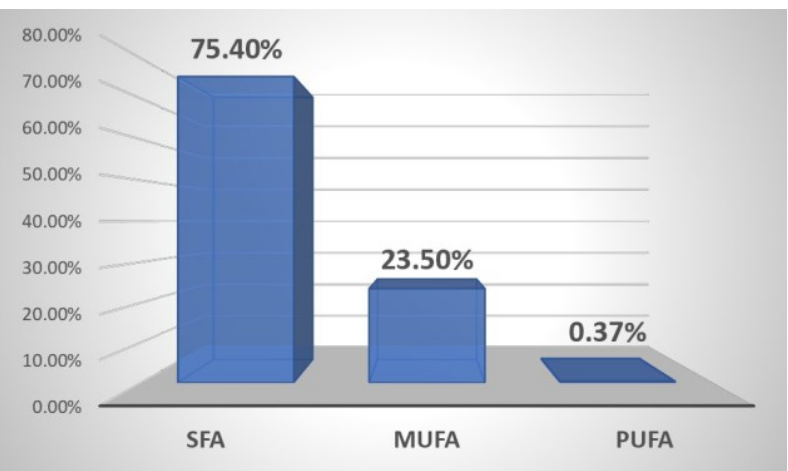

Fig. 1. Average content of saturated, monounsaturated, and polyunsaturated fatty acids in the fat from the eggs of common garden snails

According to $\mathrm{FAO} / \mathrm{WHO}$ experts, the ratio of saturated to mono- and polyunsaturated fatty acids in the human diet should be 1:1:1 (14). Saturated fatty acids are used almost exclusively as an interim or auxiliary energy source, while monounsaturated fatty acids play a role in the prevention of cardiovascular diseases. The relatively high levels of these in common garden snail eggs do not differ much from those in the fish roe of predominantly marine species $(20.3 \%-49.8 \%)$ (4). From the nutritional point of view, the presence and reciprocal ratio of polyene acids, especially the essential fatty acids, are the most important. The level of these acids in snail eggs is very low. There were only two acids from the $\omega-6$ (n-6) family found, linoleic acid and linolelaidic acid. There were no acids from the $\omega-3(n-3)$ family in the studied samples of half-products or final product. In contrast to the eggs of common garden snails, fish roe, and in particular that of marine varieties, is considered a valuable source of PUFAs (36.1\%-48.9\%), especially long-chain n-3 docosahexaenoic (DHA) (10.3\%$33.2 \%$ ), and eicosapentaenoic (EPA) (4.7\%-11.91\%) acids $(4,12)$. The available literature lacks data regarding the fatty acid profile for eggs of common garden snails. It was only determined that the perivitelline fluid contains triglycerides and cholesterol stored in lipid droplets, which constitute an energy source for the foetus (8). According to Górka et al. (2), raw large common garden snail eggs contain $0.0077 \mathrm{mg} / \mathrm{g}$ of cholesterol. Carbohydrates are key energetic compounds in snail eggs. The raw meat of common garden snails from the Cornu genus also contains little fat $(0.43 \%-$ $0.59 \%)(7,10,17)$. This fat, however, has high nutritional value due to its high content of unsaturated fatty acids, favourable ratio of n6:n3 fatty acids, and appropriate ratio of PUFA:MUFA (16).

To conclude, the present study showed that the fat contained in common garden snail eggs holds low nutritional value due to its high content of saturated and very low content of polyunsaturated acids. It also demonstrated that the production process does not influence the level of fatty acids in the final product, since there were no significant differences in the levels of individual fatty acids in the SFA, MUFA, and PUFA groups between the half-products or between the halfproducts and the final product. 
Conflict of Interests Statement: The authors declare that there is no conflict of interests regarding the publication of this article.

Financial Disclosure Statement: The manuscript was supported by Grant for Young Scientists no. WKH/MN/1 of the University of Life Sciences in Lublin, Poland.

Animal Rights Statement: None required.

\section{References}

1. Bronzi P., Rosenthal H.: Present and future sturgeon and caviar production and marketing: a global market overview. J Appl Ichthyol 2014, 30, 1536-1546.

2. Górka A., Oklejewicz B., Duda M.: Nutrient content and antioxidant properties of eggs of the land snail Helix aspersa maxima. J Nutr Food Sci 2017, 7, 1-4.

3. Hill R.S., Bowen I.D.: Studies on ovotestis of the slug Agriolimax reticulatus (Müller). Cell Tissues Res 1976, 173, 465-482.

4. Kaliniak A., Florek M., Skałecki P.: Profile of fatty acids in meat, roe, and liver of fish. Żywn Nauk Technol Ja 2015, 2, 29-46.

5. Maćkowiak-Dryka M.: Nutritional value and microbiological quality of eggs of snails of the Cornu genus. Doctoral Dissertation. University of Life Sciences, Lublin, Poland, 2017.

6. Massari S., Pastore S.: Heliciculture and snail caviar: new trends in the food sector. Monograph: Future trends and challenges in the food sector. Polish Society of Commodity Science, Cracow, 2014, pp. 79-90.

7. Murphy B.: Breeding and growing snails commercially in Australia. A report for the Rural Industries Research and Development Corporation. Rural Industries Research and Development Corporation, Moruya, 2001.
8. Nicolai A., Filser J., Lenz R., Valérie B., Charrier M. Composition of body storage compounds influences egg quality and reproductive investment in the land snail Cornu aspersum. Can J Zool 2012, 90, 1161-1170.

9. Nunes Almeida G.: Caviar Pearl, study of physical-chemical and microbiological stability. Master's Dissertation in Food Security. Faculty of Veterinary Medicine, Technical University of Lisbon, Lisbon, 2014.

10. Paszkiewicz W., Ziomek M., Szkucik K., Maćkowiak-Dryka M.: Production and quality of snail meat. Med Weter 2014, 70, 673-679.

11. Polish General Veterinary Inspectorate: Lists and registers, Animals, Zones/Compartnets and Laboratories. http://www. wetgiw.gov.pl/english/lists-and-registers.

12. Șengör G.F., Özden Ö., Erkan N., Tüter M., Aksoy H.A.: Fatty acid compositions of flathead grey mullet (Mugil cephalus L., 1758 ) fillet, raw and bees-waxed caviar oils. Turkish J Fish Aquat Sci 2003, 3, 93-96.

13. Skalmowski G.: Snails breeding and rearing - in enclosures and outdoors on grassland. Snails Garden, Pasłęk, 2010.

14. Szkucik K., Pisarski R. K., Paszkiewicz W., Pijarska I.: Carcass quality, chemical composition, and sensory characteristics of meat from broiler chickens fed growing/finishing feeds of lowered energy value. Med Weter 2009, 65, 184-187.

15. Szkucik K., Ziomek M., Maćkowiak-Dryka M., Paszkiewicz W.: Edible snails - their performance, nutritive value, and safety for consumers. Życie Wet 2011, 86, 631-635.

16. Szkucik K., Ziomek M., Paszkiewicz W., Drozd Ł., Gondek M., Knysz P.: Fatty acid in fat obtained from edible part of land snails harvested in Poland. J Vet Res 2018, 62, 519-526.

17. Ziomek M.: Nutritional value of snail meat from the Cornu genus obtained in Poland. Doctoral Dissertation. University of Life Sciences, Lublin, Poland, 2014

18. Ziomek M., Szkucik K., Maćkowiak-Dryka M., Paszkiewicz W., Drozd Ł., Pyz-Łukasik R.: Veterinary regulations for obtaining and processing edible snails. Med Weter 2017, 73, 819-825. 